American Journal of Biochemistry and Biotechnology 4 (2): 73-84, 2008

ISSN 1553-3468

(C) 2008 Science Publications

\title{
Oxidative Stress in Autism: Elevated Cerebellar 3-nitrotyrosine Levels
}

\author{
${ }^{1,2}$ Elizabeth M. Sajdel-Sulkowska, ${ }^{2}$ Boguslaw Lipinski, ${ }^{3}$ Herb Windom \\ ${ }^{4}$ Tapan Audhya and ${ }^{5}$ Woody McGinnis \\ ${ }^{1}$ Department of Psychiatry, Harvard Medical School and BWH, Boston,MA \\ ${ }^{2}$ Department of Psychiatry, BWH, Boston, MA \\ ${ }^{3}$ Skidaway Institute of Oceanography, Savannah, GA \\ ${ }^{4}$ Vitamin Diagnostics, Cliffwood Beach, NJ \\ ${ }^{5}$ Ashland, OR
}

\begin{abstract}
It has been suggested that oxidative stress and/or mercury compounds play an important role in the pathophysiology of autism. This study compared for the first time the cerebellar levels of the oxidative stress marker 3-nitrotyrosine (3-NT), mercury $(\mathrm{Hg})$ and the antioxidant selenium (Se) levels between control and autistic subjects. Tissue homogenates were prepared in the presence of protease inhibitors from the frozen cerebellar tissue of control $(n=10$; mean age, 15.5 years; mean PMI, 15.5 hours) and autistic ( $n=9$; mean age 12.1 years; mean PMI, 19.3 hours) subjects. The concentration of cerebellar 3-NT, determined by ELISA, in controls ranged from 13.69 to $49.04 \mathrm{pmol} \mathrm{g}^{-1}$ of tissue; the concentration of 3-NT in autistic cases ranged from 3.91 to $333.03 \mathrm{pmol} \mathrm{g}^{-1}$ of tissue. Mean cerebellar $3-N T$ was elevated in autism by $68.9 \%$ and the increase was statistically significant $(\mathrm{p}=0.045)$. Cerebellar $\mathrm{Hg}$, measured by atomic absorption spectrometry ranged from 0.9 to $35 \mathrm{pmol} \mathrm{g}^{-1}$ tissue in controls $(n=10)$ and from 3.2 to $80.7 \mathrm{pmol} \mathrm{g}^{-1}$ tissue in autistic cases $(n=9)$; the $68.2 \%$ increase in cerebellar $\mathrm{Hg}$ was not statistically significant. However, there was a positive correlation between cerebellar 3-NT and Hg levels $(\mathrm{r}=0.7961, \mathrm{p}=0.0001)$. A small decrease in cerebellar Se levels in autism, measured by atomic absorption spectroscopy, was not statistically significant but was accompanied by a $42.9 \%$ reduction in the molar ratio of $\mathrm{Se}$ to $\mathrm{Hg}$ in the autistic cerebellum. While preliminary, the results of the present study add elevated oxidative stress markers in brain to the growing body of data reflecting greater oxidative stress in autism.
\end{abstract}

Key words: Protein nitration, oxidative stress markers, antioxidants, autistic-pathology, nitrotyrosine, mercury, selenium

\section{INTRODUCTION}

Role of oxidative stress in the pathology of neuropsychiatric disorders: There is growing evidence supporting the role of oxidative stress in the pathophysiology of a number of neurodegenerative diseases such as amyotrophic lateral sclerosis (ALS), Parkinson's disease (PD) and Alzheimer's disease $(\mathrm{AD})^{[1]}$. There is also emerging evidence supporting the role of oxidative stress involvement in autism ${ }^{[2-8]}$. The support comes from observations of increased lipooxidation markers in blood ${ }^{[2,4]}$ and in urine ${ }^{[5,6]}$ and increased nitric oxide $(\mathrm{NO})^{[2,7,8]}$ and thiobarbituric acid-reacting substances ${ }^{[2]}$ in autism. There is also evidence for the disruption of antioxidant defense mechanisms in autism manifested by lower than control levels of glutathione peroxidase (GSPHx ${ }^{[9,10]}$, by lower levels of plasma glutathione levels and higher ratios of oxidized glutathione to reduced gluathione ${ }^{[11,12]}$, lower levels of two major serum antioxidant metalloproteins ceruloplasmin (copper-binding protein) and transferrin (iron-binding protein) ${ }^{[4,13]}$ and lower levels of naturally occurring free radical scavengers ${ }^{[14]}$. Impaired methionine metabolism is reported in autism and is associated with altered plasma glutathione levels ${ }^{[11,12]}$. As stressed by Kern and Jones ${ }^{[3]}$, there is a correlation between antioxidant proteins and loss of previously acquired skills in a subset of children with autism ${ }^{[13]}$.

Higher than control levels of circulating prooxidant organic toxins, heavy metals, xanthine oxidase and cytokines have also been observed in autism ${ }^{[14]}$. A strong oxidant, homocysteine, is increased in plasma from children with autism ${ }^{[15]}$. An increase in prooxidative inflammatory cytokines has been reported in

Corresponding Author: $\quad$ Elizabeth M. Sajdel-Sulkowska, D.Sc., Harvard Medical School/Brigham and Women's Hospital, Department of Psychiatry, BLI-151, 221 Longwood Ave., Boston, MA 02115, USA 
autistic brain tissue ${ }^{[16]}$. Hypoperfusion, promoting oxidative stress, has been documented in several regions of autistic brains by both SPECT and PET scans $^{[17]}$.

Oxidative stress markers in autism: Little is known about oxidative stress markers in autism. While data on oxidative lipid modification has been derived from plasma and urine analysis, modification to proteins and DNA has not been explored in autism. Further, there are no published data reflecting modification of brain protein or DNA by excess free radicals, nor there is prior measurement of substances known to modulate levels of oxidative stress, other than elevated parenchymal and cerebrospinal inflammatory cytokines $^{[16]}$. The approach used in this study is a logical extension of the proposed role of oxidative stress in other neuropsychiatric disorders. In $\mathrm{AD}$, for instance, examination of postmortem brain demonstrated elevated nitrotyrosine, as well as elevated carbonyls, oxidized DNA bases and lipid peroxidation products $^{[18]}$.

The present study examined cerebellar levels of 3nitrotyrosine (3-NT), a relatively specific marker of oxidative damage mediated by peroxynitrite, which is formed by the reaction of superoxide with nitric oxide (NO) on tyrosine residues in proteins ${ }^{[19]}$ or by reaction of nitrite and hydrogen peroxide ${ }^{[20]}$. Transition metal homeostasis, redox activity and levels of metalloenzymes, such as transferrin, ceruloplasmin and superoxide dismutase (SOD), all are involved in this process $^{[97]}$. It has been shown that peroxynitrite formation is downregulated by metalloenzyme such as SOD $^{[98]}$. Increased levels of NO metabolites (nitrite and nitrate) in red blood cells ${ }^{[7]}$ and plasma ${ }^{[8]}$ combined with decreased levels of metalloenzymes $\left[\begin{array}{lll}4, & 10, & 13\end{array}\right]$ reported in autism could favor formation of nitrotyrosine. Increased brain nitrotyrosine in Alzheimer's disease $\left.\mathrm{s}^{[21,} 99,100\right]$ is associated with increased levels of NO in platelets ${ }^{[22]}$.

Implication of environmental factors in autism: heavy metals: Many environmental factors have been implicated in autism, including pesticides ${ }^{[23,}{ }^{24]}$, mercury $(\mathrm{Hg})^{[25,26]}$, lead ${ }^{[27]}$ and perhaps polychlorinated biphenyls $(\mathrm{PCBs})^{[28]}$. These environmental factors share the ability to induce oxidative stress. Pesticides stimulate free radical production, induce lipid peroxidation and disturb the body's antioxidant status $^{[23]}$. Lead induces oxidative stress and increases DNA damage ${ }^{[29]}$. PCBs induce lipid peroxidation ${ }^{[30]}$. Urinary porphyrin profiles strongly suggest heavy metal toxicity in autism ${ }^{[31]}$.
Major sources of human exposure to $\mathrm{Hg}$ are primarily from eating high levels of marine fish or inland fish raised in waters contaminated by the past industrial activities, such as chlorine production [32, 33] and chronic inhalation of $\mathrm{Hg}$ gas associated with metal ore mining and processing (e.g. gold). More insidious environmental contamination such as in southern New Jersey, where industrial waste disposal has led to the contamination of potable water ${ }^{[34]}$ that eventually resulted in direct human exposure to $\mathrm{Hg}$ gas, may be responsible for additional exposure. Local environmental release of $\mathrm{Hg}$ resulting in increased air concentrations of $\mathrm{Hg}$ has been associated with higher incidence of autism in Texas ${ }^{[35]}$ and California ${ }^{[36]}$.

Mercury strongly associates with oxidative stress $^{[25,}{ }^{26]}$. Methyl mercury (MeHg) increases oxidative stress in primary neuronal culture ${ }^{[37]}$ and inhibits brain cytochrome ${ }^{[38]}$. Inorganic $\mathrm{Hg}$ induces oxidative stress in in vitro synaptosome preparations ${ }^{[39]}$ and its administration in vivo enhanced lipid peroxidation in the rat cerebral cortex and cerebellum $^{[40]}$. Hg-induced injury to human glioma cells can be prevented by specific hydroxyl radical scavengers ${ }^{[41]}$. Brain $\mathrm{Hg}$ levels have not been measured previously in autism. The studies discussed here do not consider the source of $\mathrm{Hg}$ exposure and uptake but rather aim to define the relationship between brain oxidative stress markers and brain $\mathrm{Hg}$ levels. $\mathrm{Hg}-$ induced oxidative stress results in oxidative modification of DNA, protein and lipids, as well as inhibition of the enzymes crucial for the brain development ${ }^{[42]}$. Thus, elevated levels of mercury in brain potentially interfere with normal brain development.

Antioxidant status in autism: This study also examined brain levels of antioxidant, selenium (Se). Antioxidant deficiency has been implicated in the pathophysiology of autism as reviewed by McGinnis ${ }^{[14]}$. It has been observed that levels of antioxidants are lower in autistic individuals; for example, decreased Se levels in the red blood cells have been reported in autism $^{[43]}$. Se is an essential trace element for animals and humans, which is taken up from the soil in plants. Due to geographical and regional variations of Se concentration in water and in soil, its uptake differs greatly depending on location and dietary habits. It has been suggested that supra-nutritional levels of Se may be needed to prevent degenerative disease ${ }^{[44]}$. The biological significance of Se and selenocompounds has been recently reviewed by Whanger ${ }^{[45]}$. Se is an essential component of various enzymes, such as glutathione peroxidase (GSHPx). Lower levels of Se 
and GSPHx in autistic children ${ }^{[10]}$ may favor lipid peroxidation. Se is also a component of enzymes involved in conversion of $\mathrm{T} 4$ to $\mathrm{T} 3^{[46]}$, which is critical for normal brain development. It is thus of interest that hypothyroidism has been reported in autistic children $^{[102]}$. Another, less known function of Se is its ability to counteract the neurotoxicity of heavy metals, such as $\mathrm{Hg}^{[47]}$. Since $\mathrm{Se}^{[48]}$ has been shown to accumulate preferentially in brain tissue, direct measures of this trace element in the brain are critical to our understanding of the role of Se deficiency in the pathology of autism.

The present study compares the concentrations of 3-NT, Hg and Se in cerebellar tissue from control and autistic cases. The data should be viewed as preliminary, owing to small sample size and heterogeneity within both control and autistic cohorts. The relationship of the measured parameters to abnormal neurodevelopment or expression of symptoms in autism remains, at this time, hypothetical pending more extensive studies.

\section{MATERIALS AND METHODS}

Human brain samples: Human postmortem frozen cerebellar tissue samples were obtained from the NICHD Brain and Tissue bank for Developmental Disorders at the University of Maryland, with the exception of one sample obtained from the Harvard Brain Bank. The use of the postmortem tissue has been approved by Protocol\# 2000-P-001686/4. Donor profile is presented in Table 1. Analyses of tissue levels of 3NT, Hg and Se were performed blindly.

Determination of cerebella 3-NT: Cerebellar 3-NT was measured according to the procedure previously described $^{[49]}$. In brief, cerebellar homogenates were prepared in phosphate buffered saline (PBS) containing protease inhibitors (Complete, EDTA-free protease inhibitor cocktail, Boehringer Mannheim, Indianapolis, IN), $0.5 \%$ Nonident P40, $0.5 \%$ sodium deoxycholate and $0.1 \%$ sodium dodecyl sulfate (SDS; Sigma, St Louis, MO). The homogenates were centrifuged at $10,000 \times \mathrm{g}$ for $10 \mathrm{~min}$. The supernatants were assayed for 3-NT content using Nitrotyrosine ELISA Kit (Oxis International Inc., Portland, OR) according to manufacturer's instructions. Briefly, the samples were incubated in microtiter wells coated with antibody to nitrotyrosine. A biotynylated secondary antibody was used and the product of the reaction of streptavidinperoxidase with tetramethyl benzidine as a substrate was measured by absorbancy at $450 \mathrm{~nm}$. Data is expressed as 3-NT levels in picomoles per gram of tissue.

Analysis of cerebellar Hg levels: Approximately 0.5 grams of homogenate used for 3-NT analysis was preincubated for one hour with trace metal-free $\mathrm{HNO}_{3}$ and then digested using a CEM MS-2100 microwave digestion system. An aliquot of digested homogenate was then incubated with Hg-free water, HCL and $0.1 \mathrm{~N}$ $\mathrm{BrO}_{3} \mathrm{Br}$ solution overnight in dark. Following the incubation, a hydroxylamine hydrochloride solution was added to reduce the $\mathrm{BrO}_{3} \mathrm{Br}$ in the sample. Different $\mathrm{Hg}$ standards were processed in the same manner. Samples were mixed with a stannous chloride solution using a four channel peristaltic pump and delivered into a closed gas/liquid Tekran separator which volatilizes the $\mathrm{Hg}$ which was then collected on a gold sand trap. The trap was dried for approximately 5 minutes with UHP argon (Ar) gas and was then heated and purged with $\mathrm{Ar}$ to sweep the $\mathrm{Hg}$ vapor into a Tekran cold vapor atomic fluorescence spectrophotometer (CVAFS) Hg Detector 2500. Using a HP Integrator, the peak area of the response was determined and compared to a standard curve of peak area versus $\mathrm{Hg}$ concentration.

Analysis of cerebellar Se levels: Cerebellar Se levels were measured in the same cerebellar homogenates used for 3-NT and $\mathrm{Hg}$ analysis. The analysis, performed by Vitamin Diagnostics Laboratory (Cliffwood Beach, $\mathrm{NJ}$ ), was based on the atomic absorption spectrometry (hydride method) described earlier ${ }^{[50,51]}$. Briefly, cerebellar tissue homogenates were subjected to a twostep digestion process, first with $\mathrm{HNO}_{3}$ at $135^{\circ} \mathrm{C}$ for 15 min. followed by a digestion with $\mathrm{H}_{2} \mathrm{SO}_{4}$ and $\mathrm{HClO}_{4}$ at $220^{\circ} \mathrm{C}$ for $10 \mathrm{~min}$. The solution was diluted with $\mathrm{HCl}$, reduced with $\mathrm{NaBH}_{4}$ and the Se was measured using Perkin Elmer Spectrophotometer (FIAS-100/400; cell temperature $900^{\circ}$ ) at $196 \mathrm{~nm}$ with a seronorm blood and Biorad urine used as controls.

Cell culture: Glial (C6, ATCC) cells initially were propagated in F12 medium (ATCC) containing 15\% horse serum and $2.5 \%$ fetal bovine serum and gradually adapted to serum- free medium-Stemline Neural Stem Cell Expansion Medium (Sigma). Prior to the analysis, they were plated in a 96-well microtiter plate at 5,000 cells/well. Following 24 hours preincubation, MeHghydroxide (Alfa Aesar, Ward Hill, MA) was added to a final concentration of 2-4 $\mu \mathrm{M}$; to some wells, sodium selenite (Sigma) was added to a final concentration of $100 \mu \mathrm{M}$. 
All cells were incubated for an additional 24 hours. The number of viable cells at the end of incubation was determined using non-radioactive cell proliferation assay (Promega) based on the ability of viable cells to convert tetrazolium salt into formazan that can be detected by spectrophotometry. Following incubation overnight, the optimized dye solution (containing tetrazolium salts) was added to each well and incubated for an additional 4 hours. At this time, a stop/digestion solution was added to each well, followed by additional incubation for 1 hour. The absorbancy was measured at $570 \mathrm{~nm}$.

Statistical analysis: Data was analyzed by ANOVA. The relationship between cerebellar 3-NT and $\mathrm{Hg}$ was subjected to regression analysis. All values are reported as Mean \pm SE. For all statistical tests, the 0.05 level of confidence was accepted for statistical significance.

\section{RESULTS}

3-NT in human postmortem cerebellar tissue: The data on cerebellar 3-NT is presented in Fig. 1. The levels of 3-NT were significantly increased in cerebellar tissue from autistic subjects $(n=6 ; p=0.045)$, as compared to control subjects $(n=9)$. There was a $68.9 \%$ increase in 3-NT levels in autism $(48.67 \pm 9.61$ pmol g $\left.{ }^{-1}\right)$ vs controls $\left(28.82 \pm 3.75 \mathrm{pmol} \mathrm{g}^{-1}\right)$. These are the first reported quantitative levels of 3-NT in brain tissue. Prior reports on an increased $3 \mathrm{NT}$ in brain of Alzheimer's patients were based on immunohistochemical methods ${ }^{[21,}$ 99, 100]; the most recent study reported relative 3-NT brain content ${ }^{[101]}$. Plasma concentration of 3-NT, in healthy controls, ranges from $1.63 \pm 0.15 \mathrm{ng} \mathrm{mg}^{-1} \operatorname{protein}^{[52]}$ to $35.21 \pm 4.87 \mathrm{ng} \mathrm{mL}^{-1}(135.4 \pm 18.7 \mathrm{nM})$. The urinary 3NT levels in healthy human volunteers range from 1.6 to $33.2 \mathrm{nM}^{[53]}$. In nasal lavage fluid of rhinitis patients, 3 -NT concentration of $41.40 \pm 20.96 \mathrm{ng} \mathrm{mL} \mathrm{m}^{-1}$ $(159.02 \pm 80.6 \mathrm{nM})$ has been reported ${ }^{[54]}$.

Analysis of cerebellar Hg levels. Hg levels were measured in the same homogenates used for 3-NT analysis. The data reported in Table 2, suggest a $68.2 \%$ increase in cerebellar $\mathrm{Hg}$ in autism but the increase at this point is not statistically significant.

Relationship between cerebellar 3-NT and Hg levels: Initial analysis of cerebellar 3-NT and $\mathrm{Hg}$ levels suggest a correlation with $\mathrm{r}=0.7961(\mathrm{p}=00113)$.

Analysis of cerebellar Se levels: Se levels were measured in the same cerebellar homogenates used for

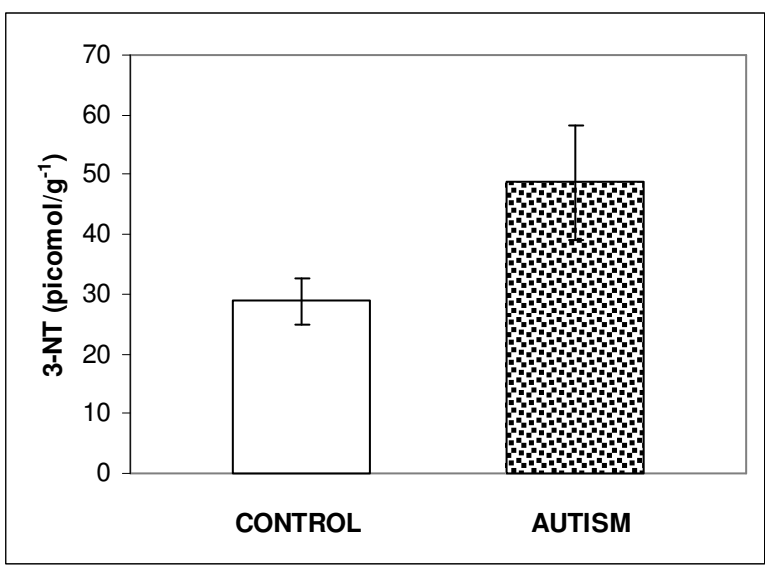

Fig. 1: 3-NT levels in cerebella from control and autistic subjects. Cerebellar 3-NT was measured with ELISA and recorded as absorbance at $450 \mathrm{~nm}$. Data are converted to picomole per gram of tissue $\left(\mathrm{pmol} \mathrm{g}^{-1}\right)$ and presented as Mean \pm SEM of control $(n=9)$ and autistic $(n=6)$ cases; $p<0.05$

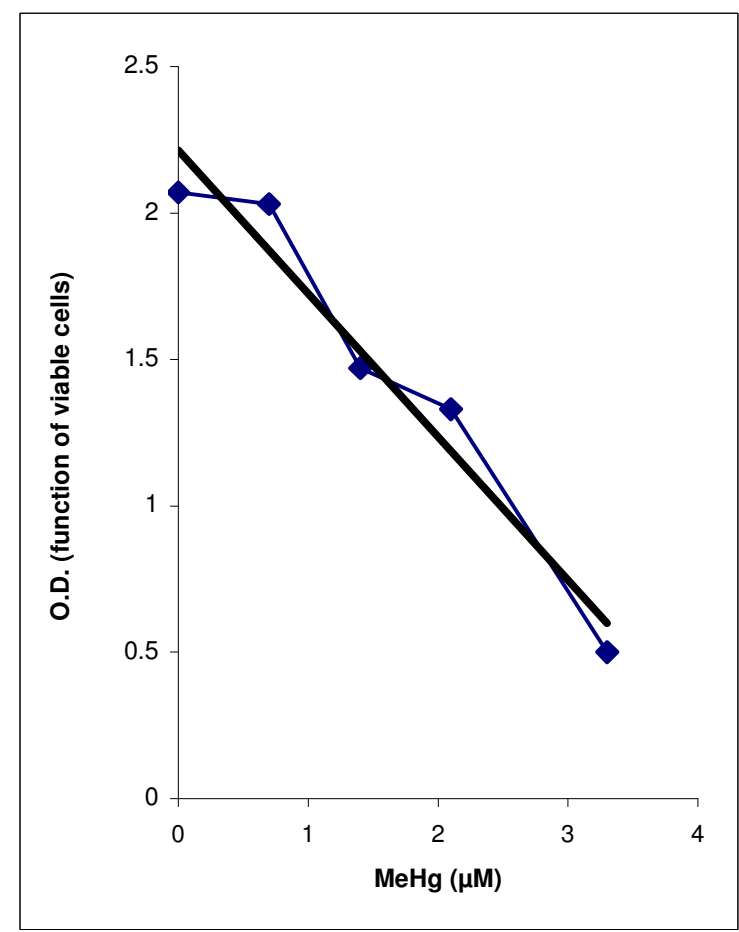

Fig. 2: Effect of MeHg cytotoxicity in human glioma (C6) cells. Cells were exposed to 2-4 $\mu \mathrm{M} \mathrm{MeHg}$ for $24 \mathrm{hrs}$. The cell viability was measured by a non-radioactive cell proliferation assay. Data are plotted as O.D. units, related to the number of viable cells vs. $\mathrm{MeHg}$ concentration in micromoles $(\mu \mathrm{M})$

3-NT and Hg analysis. The recovery of Se was over 90 percent and the limit of detection was $0.1 \mathrm{ng}$. The data shown in Table 3 indicates a small (5.7\%) decrease in cerebellar Se level in autism, but the decrease was not statistically significant. It is, however, of interest that 
Am. J. Biochem. \& Biotech., 4 (2): 73-84, 2008

Table 1: Distribution of control and autistic donors of cerebellar samples

\begin{tabular}{llllllllll}
$\begin{array}{l}\text { CASE } \\
\#\end{array}$ & DIAGN. & $\begin{array}{l}\text { AGE } \\
\text { (Years) }\end{array}$ & SEX & $\begin{array}{l}\text { PMI } \\
\text { (Hours) }\end{array}$ & $\begin{array}{l}\text { CASE } \\
\#\end{array}$ & DIAGN & $\begin{array}{l}\text { AGE } \\
\text { (Years) }\end{array}$ & $\begin{array}{l}\text { SEX } \\
\text { PMI } \\
\text { (Hours) }\end{array}$ \\
\hline 1376 & $\mathrm{C}$ & 37 & $\mathrm{M}$ & 12 & 4321 & $\mathrm{~A}$ & 9 & $\mathrm{M}$ & 12 \\
738 & $\mathrm{C}$ & 9 & $\mathrm{~F}$ & 12 & 967 & $\mathrm{~A}$ & 32 & $\mathrm{M}$ & 30 \\
1080 & $\mathrm{C}$ & 16.5 & $\mathrm{M}$ & 21 & 797 & $\mathrm{~A}$ & 9 & $\mathrm{M}$ & 13 \\
1670 & $\mathrm{C}$ & 13 & $\mathrm{M}$ & 5 & 4849 & $\mathrm{~A}-\mathrm{ADI}-\mathrm{R}$ & 7 & $\mathrm{M}$ & 20 \\
4722 & $\mathrm{C}$ & 14.5 & $\mathrm{M}$ & 16 & 732 & $\mathrm{~A}$ & 15 & $\mathrm{M}$ & 28 \\
4898 & $\mathrm{C}$ & 7.5 & $\mathrm{M}$ & 12 & 1349 & $\mathrm{~A}$ & 5.5 & $\mathrm{M}$ & 39 \\
1708 & $\mathrm{C}$ & 8 & $\mathrm{~F}$ & 20 & 4925 & $\mathrm{~A}$ & 9 & $\mathrm{M}$ & 27 \\
1500 & $\mathrm{C}$ & 7 & $\mathrm{M}$ & 18 & 4899 & $\mathrm{~A}$ & 14 & $\mathrm{M}$ & 9 \\
1136 & $\mathrm{C}$ & 34 & $\mathrm{~F}$ & 19 & 4721 & $\mathrm{~A}$ & 8 & $\mathrm{M}$ & 16 \\
1706 & $\mathrm{C}$ & 8.5 & $\mathrm{~F}$ & 20 & & & &
\end{tabular}

C, control cases $(\mathrm{n}=10)$; A, autistic cases $(\mathrm{n}=9)$; All samples were obtained from the NICHD Brain and Tissue Bank for Developmental Disorders at the University of Maryland with the exception of sample 4925 obtained from the Harvard Brain Bank. The ages are rounded to the nearest year, and postmortem interval (PMI) is recorded in hours.

Table 2:Hg levels in cerebella from autistic and control subjects. Cerebellar $\mathrm{Hg}$ was measured by atomic fluorescence spectrometry. Data are converted to picomole per gram of tissue $\left(\mathrm{pmol} \mathrm{g}^{-1}\right.$ ) and presented as Mean \pm SEM of control $(n=9)$ and autistic $(n=6)$ cases; the increase was not statistically significant

\begin{tabular}{lc}
\hline Diagnosis & $\mathrm{Hg}\left(\mathrm{pmol} \mathrm{g}^{-1}\right.$ tissue $)$ \\
Control & $14.93 \pm 3.26$ \\
Autism & $25.11 \pm 8.25$ \\
\hline
\end{tabular}

Table 3:Se levels in cerebella from autistic and control subjects. Cerebellar Se was measured by atomic absorption spectrometry. Data are converted to picomole per gram of tissue $\left(\mathrm{pmol} \mathrm{g}^{-1}\right)$ and presented as Mean \pm SEM of control $(n=9)$ and autistic $(n=6)$ cases; the difference was not statistically significant

\begin{tabular}{ll}
\hline Diagnosis & $\mathrm{Se}\left(\mathrm{pmol} \mathrm{g}^{-1}\right.$ tissue $) \times 10^{3}$ \\
Control & $2.52 \pm 0.12$ \\
Autism & $2.38 \pm 0.12$ \\
\hline
\end{tabular}

Table 4:Effect of MeHg cytotoxicity in human glioma (C6) cells. Cells were exposed to $2-4 \mu \mathrm{M} \mathrm{MeHg}$ for $24 \mathrm{hrs}$ in the absence or presence of $100(\mu \mathrm{M})$ Se. The cell viability was measured by a non-radioactive cell proliferation assay. Data are presented as O.D. units, related to the number of viable cells. Data are mean of three determinations

\begin{tabular}{lll}
\hline Treatment & O.D. (Units) & Inhibition (\%) \\
\hline Control & 1.85 & 0 \\
$\mathrm{MeHg}(2.0 \mu \mathrm{M})$ & 1.16 & 37.3 \\
$\mathrm{MeHg}(2.0 \mu \mathrm{M})+\mathrm{Se}(100 \mu \mathrm{M})$ & 1.41 & 23.8 \\
\hline
\end{tabular}

the highest cerebellar Se concentration $\left(3,190 \mathrm{pmol} \mathrm{g}^{-1}\right)$ was observed in the controls.

Relationship between cerebellar Se and $\mathrm{Hg}$ levels: While, the decrease in cerebellar Se in autism was not significant, it was accompanied by a $42.9 \%$ reduction in the molar ratio of $\mathrm{Se}$ to $\mathrm{Hg}$ from 407.4 in control to 232.9 in the autistic cerebellum. Since Se is involved in binding of $\mathrm{Hg}$ in the brain, a decrease in $\mathrm{Se} / \mathrm{Hg}$ molar ratio in autism may reflect a relative deficiency in this antioxidant that could further exacerbate $\mathrm{Hg}$ toxicity.
Effect of methyl $\mathrm{Hg}$ and $\mathrm{Se}$ on glioma (C6) cells in culture: The effect of $\mathrm{MeHg}$, known to induce oxidative stress in glioma (C6) cells is shown in Fig. 2 and Table 4. The addition of $\mathrm{MeHg}$ to $\mathrm{C} 6$ cell cultures resulted in decreased O.D. readings indicating reduced number of viable cells; this reduction was dosedependent as shown in Fig. 2. The simultaneous addition of $\mathrm{Se}(100 \mu \mathrm{M})$ partially counteracted cytotoxicity of $\mathrm{MeHg}$ (Table 4).

\section{DISCUSSION}

Implications of increased cerebellar 3-NT in autism: Although a large body of evidence implicates oxidative stress in the pathogenesis of neurodegenerative and neuropsychiatric disorder, relatively few systematic studies document changes in oxidative stress markers, especially those related to protein modification. The 3NT is a specific marker for oxidative damage to proteins. Increased brain levels of 3-NT has been documented in Alzheimer's disease and Parkinson's disease by immunohistochemical methods [21, 99, 100]. While the most recent study reported relative increase in 3-NT brain content in Alzheimer's disease ${ }^{[101]}$, there are no reports of quantitative brain levels of this oxidative stress marker in humans. The 3-NT in mice liver is reported at concentration ranging from 0.17 to 0.3 pmol per mg protein ${ }^{[60]}$. Thus, our report contains novel data on brain 3-NT levels and the evidence of an increase in brain levels of 3-NT in autism.

Increased nitration of proteins has been documented in multiple pathologies. The proteonomic approach identified specific target proteins in the Alzheimer's hippocampus ${ }^{[61]}$. A more recent study has identified 32 unique nitrotyrosine sites within 29 different proteins with more than half of these proteins 


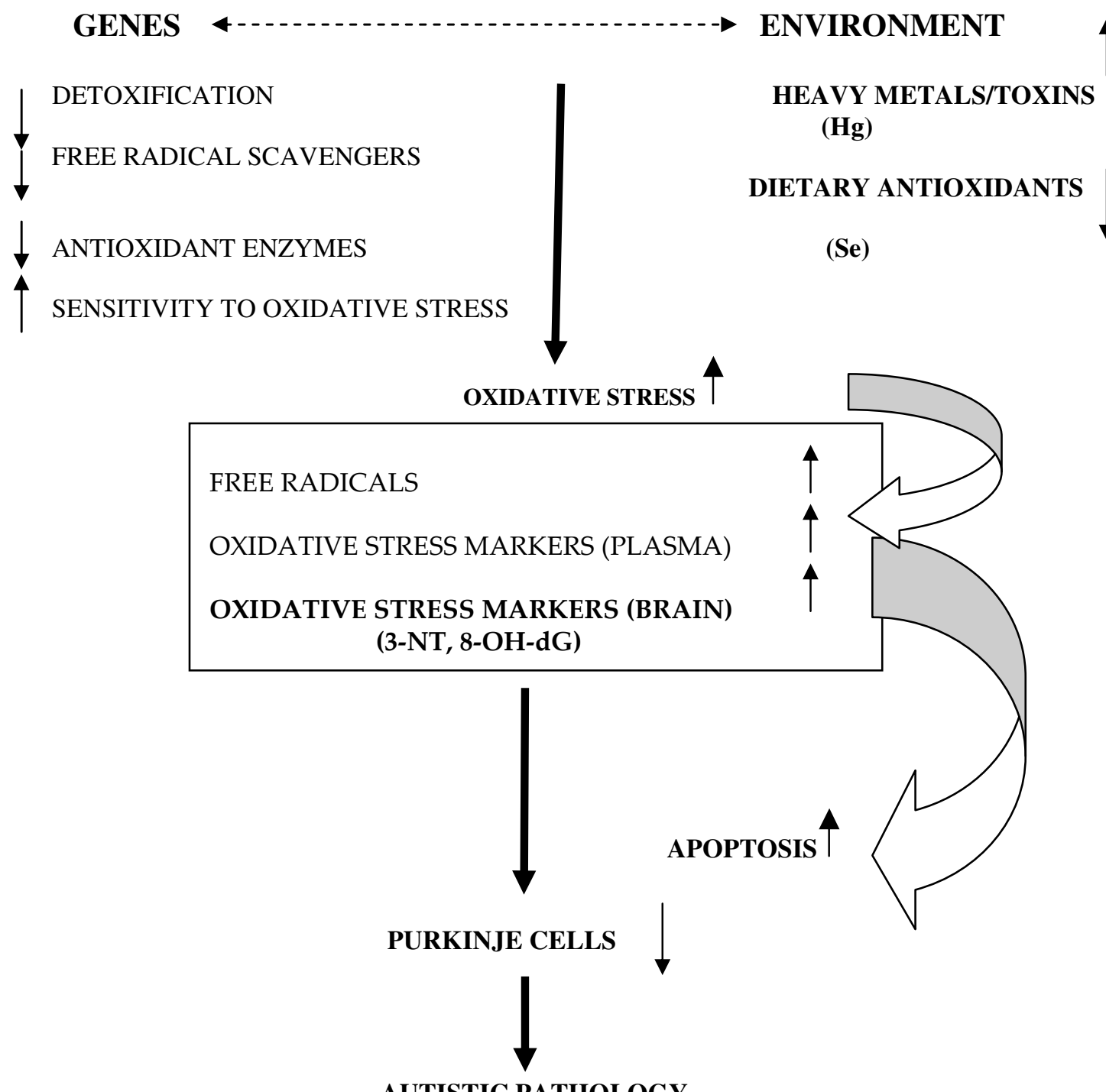

Fig. 3: A potential model of oxidative-stress-mediated gene-environment interactions in autism

being involved in Parkinson's disease, Alzheimer's disease and other degenerative diseases ${ }^{[62]}$. With regard to nitration of specific brain proteins, three - glial fibrillary acidic protein (GFAP), synaptophysin and superoxide dismutase (SOD) - may be particularly relevant to autism. GFAP is elevated in the CSF of children with autism ${ }^{[63,64]}$ and in autistic brain tissue ${ }^{[65,}$ 66]. Nitration of GFAP in the rat brain has been identified by proteomics ${ }^{[1]}$. A reduced density of synaptophysin-expressing synaptic vesicles has been observed in autism ${ }^{[67,68]}$. Our own observations suggest a decrease in synaptophysin levels in the cerebella of subjects with autism ${ }^{[65]}$. The reduction in synaptophysin expression may contribute to altered behavior in autism, since animals with a spatial learning deficit display a significant reduction in synaptophysin levels ${ }^{[69]}$. Synaptophysin has been shown to be the main target of nitration in the rat hippocampus following the infusion of amyloid beta-protein [70]. SOD is an endogenous scavenger of superoxide anions ${ }^{[71]}$. Decreased plasma levels of SOD have been observed in autism ${ }^{[10,13]}$. Nitration of SOD has been observed in the aging heart ${ }^{[72]}$ and under conditions of oxidative stress in mice $^{[73]}$. Thus, the increase in the overall nitration level in the cerebella of subjects with autism predicts oxidative stress-related modification of proteins relevant to autistic pathology. Altered levels of proteins combined with their oxidative modification could affect significantly cerebellar development, resulting in autistic pathology. 
Increased cerebellar $\mathrm{Hg}$ in autism? $\mathrm{Hg}$ is a developmental neurotoxicant. CDC reports that between 316,588 and 637,233 children each year have umbilical cord blood $\mathrm{Hg}$ levels $>5.8$ micrograms per liter, which is associated with loss of $\mathrm{IQ}^{[75]}$. The studies on the role of mercury in the pathogenesis of autism have yielded conflicting results. Some studies suggest a potential link between environmental $\mathrm{Hg}$ exposure and autism $^{[25,26,31,35]}$. The evidence implicating $\mathrm{Hg}$ in oxidative stress is even more abundant ${ }^{[37-41]}$.

Few studies to date report brain $\mathrm{Hg}$ levels. Interestingly our values are within the range of reported ones. Studies of inhabitants of Southern Poland, an area of concentrated mining industry, reports brain levels of $\mathrm{Hg}$ ranging from 0-14.2 $\mathrm{ng} \mathrm{g}^{-1}$ with an average of $2.3 \pm 1.9 \mathrm{ng} \mathrm{g}^{-1}$ [55]. Studies from areas in the vicinity of $\mathrm{Hg}$ mines in Slovenia reported values ranging from $0-$ $281 \mathrm{ng} \mathrm{g}^{-1}$ [56]. Hair $\mathrm{Hg}$ levels in Japan ranged from 1.12 to $54.5 \mathrm{ng} \mathrm{g}^{-1}$. The brain levels of $\mathrm{Hg}$ in suckling rats exposed to mercury compounds increased from $33 \mathrm{ng}$ $\mathrm{g}^{-1}$ in controls to $73-108 \mathrm{ng} \mathrm{g}^{-1}$ in $\mathrm{Hg}$-treated animals ${ }^{[57]}$. While we found increased $\mathrm{Hg}$ levels in cerebella from subjects with autism, the increase was not statistically significant. However, the correlation between cerebellar $\mathrm{Hg}$ and 3-NT levels suggests that increased oxidative stress in brains of autistic subjects may be related in part to the increased mercury. It is possible that increased levels of $\mathrm{Hg}$ in the autistic brain may be caused by defects in the detoxification mechanisms as suggested by studies of Geier and Geier $^{[75]}$. Irrespective of the sources of $\mathrm{Hg}$ contamination, exposure and the mechanism involved in its accumulation in the brain, increased brain $\mathrm{Hg}$ concentration is likely to result in oxidative stress and damage to cells as indicated by the results of our glial cultures. Japanese studies have shown that $\mathrm{Hg}$ exposure, indicated by hair $\mathrm{Hg}$ levels above $6.9 \mathrm{ng} \mathrm{g}^{-1}$ (34.5 pmol $\mathrm{g}^{-1}$ ), significantly affected brain stem auditory evoked potential (BAEP) ${ }^{[76]}$. It is interesting that BAEP abnormalities have been observed in autism $^{[77]}$, although reported changes have not been consistent ${ }^{[78]}$.

Cerebellar Se in autism: It has been observed that levels of antioxidants including Se are lower in autistic individuals $^{[43]}$. Se is essential component of glutathione peroxidase (GSPHx) and a decrease in GSPHx has been observed in children with autism ${ }^{[10]}$. Another, less known function of $\mathrm{Se}$ is its ability to counteract the neurotoxicity of heavy metals, such as $\mathrm{Hg}^{[47]}$.

Se values range from 57.3 to $117.9 \mu \mathrm{g} \mathrm{L}^{-1}$ in maternal blood, from 51.1 to $104.2 \mu \mathrm{g} \mathrm{L}^{-1}$ in umbilical cord blood and from $0.56-1.06 \mu \mathrm{g} \mathrm{g}^{-1}$ in placenta ${ }^{[58]}$. Nail Se values ranging from 0.6 to $0.9 \mu \mathrm{g} \mathrm{g}^{-1[58]}$ and from 0.89 to $1.03 \mu \mathrm{g} \mathrm{g}^{-1}$ have been reported. Human brain Se concentrations of $\sim 1.4 \mathrm{nmol} \mathrm{g}^{-1}$ is also reported $^{[56]}$.

Since $\mathrm{Se}^{[48]}$ has been shown to accumulate preferentially in brain tissue, direct measures of these trace elements in the brain are critical to our understanding of the role of Se deficiency in the pathology of autism. Brain Se levels reported here are in agreement with previously reported brain $\mathrm{Se}$ concentrations $^{[56]}$. Furthermore, since $\mathrm{Se}$ binds $\mathrm{Hg}$ in the brain ${ }^{[56]}$, direct measurement of brain Se levels is important in assessing heavy metal toxicity. A decrease in $\mathrm{Se}$ to $\mathrm{Hg}$ ratio in autism observed in our study may reflect a relative deficiency in this antioxidant.

Our tissue culture studies suggest a potential effect of Se in counteracting heavy metal toxicity. These data are in agreement with observations that $\mathrm{Hg}$-induced injury to human glioma cells can be prevented by specific hydroxyl radical scavengers ${ }^{[41]}$. A greater number of samples should be tested before the deficiency of this antioxidant in autism is confirmed.

Oxidative-stress model of autistic pathology: Our finding of increased nitrotyrosine levels in autistic cerbella lends further support to the hypothesis of oxidative stress involvement in autistic pathology. While it would be important to extend this study to a greater number of cases and to verify the geographical distribution of cases to link $\mathrm{Hg}$ level to the environmental exposure, a more likely explanation for heavy metal cytotoxicity in autism is the reduced ability by autistic patients to eliminate heavy metals from their system as suggested by a decreased capacity of urinary metal excretion ${ }^{[75]}$; defective metal elimination in conjunction with the deficiency of the intrinsic antioxidant system may thus lead to oxidative brain damage. Although the level of Se is not significantly altered in autistic brain, the molar ratio of $\mathrm{Se}$ to $\mathrm{Hg}$ is significantly decreased. It has been shown that Se binds $\mathrm{Hg}$ in brain and the reduced $\mathrm{Se} / \mathrm{Hg}$ ratio may thus further enhance oxidative stress.

One of the outcomes of oxidative stress is increased apoptosis. Purkinje cells are especially sensitive to ischemia ${ }^{[79,80]}$ and hypoxia ${ }^{[79,81]}$. Oxidative stress-induced apoptosis may contribute to Purkinje cell hypoplasia observed in a subset of autistic cases, which in turn, contributes to the stereotypic behavior observed in autism. Systematic studies indicate the anatomic abnormalities in autistic brains that include reduced numbers of Purkinje cells in the cerebellum ${ }^{[82-88]}$. The 
decrease has been most consistently observed in the cerebellar hemispheres primarily in the posterior inferior region ${ }^{[88]}$. The posterior cerebellar lobes are associated with motor execution ${ }^{[89]}$ that may be affected in autism ${ }^{[90]}$. The decrease in Purkinje cell number is likely to affect the neuronal communication and could contribute to autistic behavior in light of the cerebellar involvement in motor functions and planning, learning, cognitive flexibility, sensory processing, exploratory activity and other cognitive ${ }^{[91]}$ and emotional ${ }^{[92]}$ processes. Individuals with cerebellar abnormalities exhibit greater attention-orienting deficits and visuospatial attention ${ }^{[85]}$. Early vermal cerebellar lesions, such as tumor removals, lead to behavioral disturbances similar to those found in autism ${ }^{[93]}$. The rates of stereotyped behavior in autism were positively correlated with the magnitude of cerebellar hypoplasia ${ }^{[94]}$.

Based on the cumulative evidence of aforementioned data and the findings derived from our study, we propose a tentative oxidative-stress-mediated model of autistic pathology (Fig. 3). This model incorporates possible environmental impacts and is also consistent with recent genetic analysis that identified several genes linked to autism. Interestingly enough, some of these genes code for factors involved in the antioxidant defense mechanism such as glutathione-Stransferase (GST M1) ${ }^{[12,95]}$ an allele involved in the metabolism of glutathione, which is an intrinsic antioxidant, as well as differences in allele frequency for genes encoding reduced folate carrier ${ }^{[12]}$. Polymorphism for metal-responsive transcription factor (MTF-1) in autism ${ }^{[96],}$ potentially alters expression of metallothionein and tissue levels of heavy metals such as mercury.

In conclusion, this study examined an oxidative stress marker 3-NT, related to protein modification and two potential modulators of oxidative stress, $\mathrm{Hg}$ and $\mathrm{Se}$, in control and autistic brains. Our data indicate an increase in 3-NT levels in the autistic cerebellum, along with a positive correlation between elevated cerebellar 3-NT and high Hg levels, a trend toward decreased Se levels and a reduction in the molar ratio of $\mathrm{Se} / \mathrm{Hg}$. Caution should be applied to over interpreting these data due to the rather small sample size and heterogeneity within both control and autistic populations. The preliminary data suggest a need for more extensive studies of oxidative stress, its relationship to the environmental factors and its possible attenuation by antioxidants in autism.

\section{ACKNOWLEDGMENT}

We thank the NICDH Brain and Tissue Bank for Developmental Disorders at the University of Maryland and the Harvard Brain Bank for providing human postmortem brain specimens, and the Autism Research Institute for their generous support of this study.

\section{REFERENCES}

1. Suzuki, Y., M. Tanaka, M. Sohmiya, S. Ichinose, A. Omori and K. Okamoto, 2005. Identification of nitrated proteins in the normal rat brain using a proteomics approach. Neurol. Res., 27: 630-633.

2. Zoroglu, S.S., F. Armutcu, S. Ozen, A. Gurel, E. Sivasli, O. Yetkin and I. Meram, 2004. Increased oxidative stress and altered activities of erythrocyte free radical scavenging enzymes in autism. Eur. Arch. Psychiatr. Clin. Neurosci., 254: 143-147.

3. Kern. J.K. and A.M. Jones, 2006. Evidence of Toxicity, oxidative stress and neuronal insult in autism. J. Toxicol. Environ. Health, 9: 485-499.

4. Chauhan, A., V. Chauhan, W.T. Brown and I. Cohen, 2004. Oxidative stress in autism: increased lipid peroxidation and reduced serum levels of ceruloplasmin and transferring - the antioxidant proteins. Life Sci., 75: 2539-2549.

5. Ming, X., T.P. Stein, M. Brimacombe, W.G. Johnson, G.H. Lambert and G.C. Wagner, 2005. Increased excretion of lipid peroxidation biomarker in autism. Prostglandins Leukot. Essent. Fatty Acids, 73: 379-384.

6. Yao, Y., W.J. Walsh, W.R. McGinnis and D. Pratico, 2006. Altered vascular phenotype in autism: Correlation with oxidative stress. Arch. Neurol., 63: 1161-1164.

7. Sogut, S., S.S. Zoroglu, H. Ozyurt, H.R. Yilmaz, F. Ozugurlu, M. Tarakcioglu and O. Akyol, 2003. Changes in nitric oxide levels and antioxidant enzyme activities may have a role in the pathological mechanisms involved in autism. Clin. Chim. Acta, 331: 111-117.

8. Sweeten, T.L., D.J. Posey, S. Shankar and C.J. Mcdougle, 2004. High nitric oxide production in autistic disorder: A possible role for interferongamma. Biol. Psychiatry, 15: 434-437.

9. Golse, B., P. Debray-Ritzen, P. Durosay and K. Puget, 1978. Michelson, A.M. Alterations in two enzymes: superoxide dismutase and glutathion peroxidase in developmental infantile psychosis (infantile autism). Rev. Neurol., 134: 699-705. 
10. Yorbik, O., A. Sayal, C. Akay, D.I. Akbiyik and T Sohmen, 2002. Investigation of antioxidant enzymes in children with autistic disorder. Prostglandins Leukot. Essential Fatty Acids, 67: 341-343.

11. James, S.J., P. Cutler, S. Melnyk, S. Jernigan, L. Janak, D.W. Gaylor and J.A. Neubrander, 2004. Metabolic biomarkers of increased oxidative stress and impaired methylation capacity in children with autism. Am. J. Clin. Nutr., 80: 1611-1617.

12. James, S.J., S. Melny, S. Jernigan, M.A. Cleves, C.H. Halsted, D.H. Wong, P. Cutler, K. Bock, M. Boris, J.J. Bradstreet, S.M. Baker and D.W. Gaylor, 2006. Metabolic endothype and related genotypes are associated with oxidative stress in children with autism. Am. J. Genet. B. neuropsychiatry. Genet., 141: 947-956.

13. Chauhan A. and V. Chauhan, 2006. Oxidative stress in autism. Pathophysiology, 13: 171-181.

14. McGinnis, W.R., 2004. Oxidative stress in autism. Altern. Ther. Health Med., 10: 22-37.

15. Pasca, S.P., B. Nemes, L. Vlase, C.E. Gagyi, E. Dronca, A.C. Miu and M. Dronca, 2006. High levels of homocysteine and low serum paraoxonase 1 arylesterase activity in children with autism. Life Sci., 78: 2244-2248.

16. Vargas, D.L., C. Nascimbene, C. Krishnan, A.W. Zimmerman and C.A. Pardo, 2005. Neuroglial activation and neroinflammation in the brain of patients with autism. Ann. Neurol., 57: 67-81.

17. Rossignol, D.A. and L.W. Rossignol, 2006. Hyperbaric oxygen therapy may improve symptoms in autistic children. Med. Hypotheses, 67: 216-228.

18. Sultana, R., M. Perluigi and D.A. Buttrfield, 2006. Protein oxidation and lipid peroxidation in brain of subjects with Alzheimer's disease: insight into mechanism of neurodegeneration from redox proteonomics. Antioxid. Redox. Signal., 8: 20212037.

19. Beckman, J.S. and W.H. Koppenol, 1996. Nitric oxide, superoxide and peroxynitrite the good, the bad and the ugly. Am. J., Physiol., 271: C14241437.

20. Sampson, J.B., Y. Ye, H. Rosen and J.S. Beckman, 1998. Myeloperoxidase and horseradish peroxidase catalyze tyrosine nitration in proteins from nitrite and hydrogen peroxide. Arch. Biochem. Biophys., 356: 207-213.

21. Beal, M.F., 2002. Oxidatively modified proteins in aging and disease. Free Radic. Biol. Med., 32: 797803.
22. Vignini, A., L. Nanetti, C. Moroni, L. Tanase, M. Bartolini, S. Luzzi, L. Provinciali and L. Mazzanti, 2006. Modification of platelet from Alzheimer disease patients: a possible relation between membrane properties and NO metabolites. Neurobiol. Aging, 28: 987-994.

23. Abdollahi, M., A. Ranjbar, S. Shadnia, S. Nikfar and A. Rezaiee, 2004. Pesticides and oxidative stress: a review. Med. Sci. Monit., 10: 141-147.

24. D’Amelio, M., I. Ricci, R. Sacco, X. Liu, L. D’Agruma, L.A. Muscarella, V. Guarnieri, R. Militerni, C. Bravaccio, M. Elia, C. Schneider, R. Melmed, S. Trillo, T. Pascicci, S. Puglisi-Allegra, K.L. Reichelt, F. Macciardi, J.J. Holden and A.M. Persico, 2005. Paraoxonase gene variants are associated with autism in North America, but not in Italy: possible regional specificity in geneenvironment interactions. Mol. Psychiatry, 10: 1006-1016.

25. Mutter, J., J. Naumann, R. Schneider, H. Wlach and B. Haley, 2005. Mercury and autism: accelerating evidence? Neuro. Endocrinol. Lett., 26: 439-446.

26. Mutter, J., J. Naumann, H. Walach and F. Daschner, 2005. Amalgam risk assessment with coverage of references up to 2005. Gesundheitswesen, 67: 204-216.

27. Shannon, M. and J.W. Graef, 1996. Lead intoxication in children with pervasive developmental disorders. J. Toxicol. Clin. Toxicol., 34: 177-181.

28. Weiss, B. and P.J. Landrigan, 2000. The developing brain and the environment: an introduction. Environ. Health Perspect. , 1008 S: 373-374.

29. Bolin, C.M., R. Basha, D. Cox, N.H. Zawia, B. Maloney, D.K. lahiri and F. Cardezo-Pelaez, 2006. Exposure to lead and the developmental origin of oxidative DNA damage in the aging brain. FASEB J., 20: 788-790.

30. Muthuvel, R., P. Venkataraman, G. Krishnamoorthy, D.N. Gunadharini, P. Kanagaraj, A. Jone Stanley, N. Srinivasan, K. Balasubramanian, M.M. Aruldhas and J. Arunakaran, 2006. Antioxidant effect of ascorbic acid on PCB (aroclor 1254) induced oxidative stress in hypothalamus of albino rats. Clin. Chim. Acta, 365: 297-303.

31. Nataf, R., C. Skorupka and L. Amet, 2006. Porphyrinuria in childhood autistic disorder: implications for environmental toxicity. Toxicol. Appl. Pharmacol., 214: 99-108. 
32. Evans, D.W., R.D. Kathman and W.W. Walker, 2000. Trophic accumulation and depuration of mercury by blue crabs (Callinectes sapidus) and pink shrimp (Penaeus duorarum). Marine Res., 49: 419-434.

33. Palmer-Locarnini, S.J. and B.J. Presley, 1996. Mercury concentrations in benthic organisms from a contaminated estuary. Marine Environ. Res., 41: 225-239.

34. Murphy, E.A., J. Dooley, H.L. Windom and R.G Smith Jr., 1994. Mercury species in potable ground water in southern New Jersey. Water, Air and Soil Pollution, 78: 61-72.

35. Palmer, R.F., S. Blanchard and Z. Stein, 2006. Environmental mercury release, special education rates and autism disorder: an ecological study of Texas. Health Place, 12: 203-209.

36. Windham, G.C., L. Zhang, R. Gunier, L.A. Croen, J.K. Grether, S. Yee and B.H. Choi, 2006. Autism spectrum disorders in relation to distribution of hazardous air pollutants in San Francisco Bay Area. Environ. Health Perspect., 114: 1438-1444.

37. Kaur, H. and B. Halliwell, 1994. Evidence for nitric oxide-mediated oxidative damage in chronic inflammation. Nitrityrosine in serum and synovial fluid from rheumatoid patients. FEBS Lett., 350: 912.

38. Yee, S. and B.H. Choi, 1996. Oxidative stress in neurotoxic effects of methylmercury poisoning. Neurotoxicology, 17: 17-26.

39. Hussain, S., D.A. Rodgers, H.M. Duhart and S.F. Ali, 1997. Mercuric chloride-induced reactive oxygen species and its effect on antioxidant enzymes in different regions of rat brain. $J$. Environ. Sci. Health B., 32: 395-409.

40. Anuradha, B., M. Rajeswari and P. Varalakshmi, 1998. Degree of peroxidative status in neuronal tissues by different routes of inorganic mercury administration. Drug. Chem. Toxicol., 21: 47-55.

41. Lee, Y.W., M.S. Ha, Y.K. Kim, 2001. Role of reactive oxygen species and glutathione in inorganic mercury-induced injury in human glioma cells. Neurochem. Res., 26: 1187-1193.

42. Stamler, C.J., N. Abdelouahab, C. Vanier, D. Mergler and H.M. Chan, 2006. Relationship between platelet monoamine oxidase-B (MAOBB) activity and mercury exposure in fish consumers from the Lake St. Pierre region of Que., Canada. Neurotoxicology, 27: 429-436.

43. Audhya, T. and W.R. McGinnis, 2004. Nutrient, toxin and enzyme profile of autistic children. Abstracts of the $3^{\text {rd }}$ International Meeting for Autism Research, Sacramento CA, p.74.
44. Rayman MP., 2002. The argument for increasing selenium uptake. Proc. Nutr. Soc., 61: 203-215.

45. Whanger PD., 2002. Selenocompounds in plants and animals and their biological significance. $J$. Am. Coll. Nutr., 21: 223-232.

46. Foster, H.D., 1993. The iodine-selenium connection: its possible roles in intelligence, cretinism, sudden infant death syndrome, breast cancer and multiple sclerosis. Med. Hypothesis, 40: 61-65.

47. Whagner, P.D., 2001. Selenium and the brain: a review. Nutr. Neurosci., 4: 81-97.

48. Kohrle, J., F. Jakob, B. Contempre and J.E. Dumont, 2005. Selenium, the thyroid and the endocrine system. Endocr. Rev., 26: 944-984.

49. Beckman, J.S., 2002. Protein tyrosine nitration and peroxynitrite. FASEB J., 16: 1144.

50. Walz, B., M. Melcher and J. Neve, 1984. Determination of selenium in human body fluids by hydride generation atomic absorption spectrometry optimization of sample recomposition. Anal. Chim. Acta, 165: 131-140.

51. Ataniyazova, O.A., R.A. Baumann, A.K.D. Liem, U.A. Mukhopadhyay, E.F. Vogelaar and E.R. Boersma, 2001. Levels of certain metals, organochlorine pesticides and dioxins in cord blood, maternal blood, human milk and some commonly used nutrients in the surroundings of Aral Sea. Acta Pediatr., 90: 801-808.

52. Kingdon, E.J., A.R. Mani, M.T. Frost, C.P. Denton, S.H. Powis, C.M. Black and K.P. Moore, 2006. Low plasma protein nitrotyrosine levels distinguish primary raynaud's phenomenon from scleroderma. Ann. Rheum. Dis., 65: 952-954.

53. Tsikas, D., A. Mitschke, M.T. Suchy, F.M. Gutzki, D.O. Stichtenoth, 2005. Determination of 3nitrotyrosine in human urine at the basal state by gas chromatography-tandem mass spectrometry and evaluation of the excretion after oral intake. J. Chromatogr. B. Analyt. Technol. Biomed. Life Sci., 827: 146-156.

54. Inoue, H., K. Hisamatsu, K. Ando, R. Ajisaka and N. Kumagai, 2002. Determination of nitrotyrosine and related compounds in biological specimens by competitive enzyme immunoassay. Nitric Oxide, 7: 11-17.

55. Lech, T. and J.K. Sadlik, 2004. Total mercury in human autopsy materials from a nonexposed Polish population. Arch. Environ. Health, 59: 50-54.

56. Falnoga, I., M. Tusek-Znidaric and P. Stegnar, 2006. The influence of long-term mercury exposure on selenium availability in tissue: an evaluation of data. BioMetals, 19: 283-294. 
57. Orct, T., M. Blanusa, M. Lazarus, V.M. Vernai and K. Kostial, 2006. Comparison of organic and inorganic mercury distribution in suckling rat. J. Appl. Toxicol., 26: 536-539.

58. Lorenzo Alonso, M.J., A. Bermejo Barrera, J.A. Cocho de Juan, J.M. Fraga Bermudez and P. Bermejo Barrera, 2005. Selenium levels in related biological samples: human placenta, maternal and umbilical cord blood, hair and nails. J. Trace Elem. Med. Biol., 19: 49-54.

59. Satia, J.A., I.B. King, J.S. Morris, K. Stratton and E. White, 2006. Toenail and plasma levels as biomarkers of selenium exposure. Ann. Epidemiol., 16: $53-58$.

60. Ishii, Y., M. Iijima, T. Umemura, A. Nishikawa, Y. Iwasaki, R. Ito, K. Saito, M. Hirose and $\mathrm{H}$. Nakazawa, 2006. Determination of nitrotyrosine and tyrosine by high-performance liquid chromatography with tandem mass spectrometry and immunohistochemical analysis in livers of mice administered acetomonophen. J. Pharm. Biomed. Anal., 41: 1325-1331.

61. Sacksteder, C.A., W.J. Qian, T.V. Knyushko, H. Wang, M.H. Chin, G. Lacan, W.P. Melega, D. .G. $2^{\text {nd }}$ Camp, R.D. Smith, D.J. Smith, T.C. Squier and D.J. Bigelow, 2006. Endogenously nitrated proteins in mouse brain: links to neurodegenerative disease. Biochemistry, 45: 8009-8022.

62. Sultana, R., D. Boyd-Kimball, H.F. Poon, J. Cai, W.M. Pierce, J.B. Klein, M. Merchant, W.R. Merkesbery and D.A. Butterfield, 2006a. Redox proteonomics identification of oxidized proteins in Alzheimer's disease hippocampus and cerebellum: An approach to understand pathological and biochemical alterations in AD. Neurobiol. Aging., 27: 1564-1576.

63. Rosengren, L.E., G. Ahlsen, M. Belfrage, C. Gillberg, K.G. Haglid and A. Hamberger, 1992. A sensitive ELISA for glial fibrillary acidic protein: application in CSF of children. J. Neurosci. Methods, 44: 113-119.

64. Ahlsen, G., L. Rosengren, M. Belfrage, A. Palm, K. Haglid, A. Hamberger and C. Gillberg, 1993. Glial fibrillary acidic proteins in the cerebrospinal fluid of children with autism and other neuropsychiatric disorders. Biol. Psychiatry, 15: 734-743.

65. Sajdel-Sulkowska, E.M., 2001. Altered protein expression in autistic cerebellum. Abstract presented at the $1^{\text {st }}$ International Meeting for Autism Research, San Diego.

66. Laurence, J.A. and S.H. Fatemi, 2005. Glial fibrillary acidic protein is elevated in superior frontal, parietal and cerebellar cortices in autistic subjects. Cerebellum, 4; 206-210.
67. Belichenko, P.V., A.A., Fedorov and A.B. Dahlstro, 1996. Quantitative analysis of immunofluorescence and lipofuscin distribution in human cortical areas by dual-channel confocal scanning microscopy. J. Neurosci. Methods, 69: 155-161.

68. Bigio, E.H., M.B. Vono, S. Satumtira, J. Adamson, E. Sontag, L.S. Hynan, C.L. White, M. Baker and M. Hutton, 2001. Cortical synapse loss in progressive supranuclear palsy. J. Neuropathol. Exp. Neurol., 60: 403-410.

69. Smith, T.D., M.M. Adams, M. Gallagher, J.H. Morrison and P.R. Rapp, 2000. Circuit-specific alterations in hippocampal synaptophysin immunoreactivity predict spatial learning impairment in aged rats. J. Neurosci., 20: 65876593.

70. Tran, M.H., K. Yamada, A. Nakajima, M. Mizuno, J. He, H. Kamei and T. Nabeshima, 2003. Tyrosine nitration of synaptic protein synaptophysin contributes to amyloid beta-peptide-induced cholinergic dysfunction. Mol. Psychiatry, 8: 407412.

71. Maier, C.M. and P.H. Chan, 2002. Role of superoxide dismutase in oxidative damage and neurodegenerative disorders. Neuroscientist, 8: 323-334.

72. Kanski, J., A. Behring, J. Pelling and C. Schoneich, 2005. Proteonomic identification of 3nitrotyrosine-containing rat cardiac proteins: effects of biological aging. Am. J. Physiol. Heart Circ. Physiol., 288: H371-381.

73. Tangpong, J., M.P. Cole, R. Sultana, S. Estus, M. Vore, W. St. Clair, S. Ratanachaiyavong, D.K. St. Clair and D.A. Butterfield, 2007. Adriamycinmediated nitration of manganese superoxide dismutase in the central nervous system: insight into the mechanism of chemobrain. J. Neurochem., 100: 191-201.

74. Tranande, L., P.J. Landrigan and C. Schechter, 2005. Public health and economic consequences of methyl mercury toxicity to the developing brain. Environ. Health Perspect., 113: 590-596.

75. Geier, D.A. and M.R. Geier, 2006. A clinical trial of combined anti-androgen and anti-heavy metal therapy in autistic disorders. Neuro. Endocrinol. Lett., 27: 833-888.

76. Murata, K., M. Sakamoto, K. Nakai, P. Weihe, M. Dakeishi, T. Iwata, X.J. Liu, T. Ohno, T. Kurosava, K. Kamiya and H. Satoh, 2004. Effects of methylmercury on neurodevelopment in Japanese children in relation to the Madeiran study. Int. Arch. Occup. Environ. Health, 77: 571-579.

77. Skoff, B.F., A.F. Mirsky and D. Turner, 1980. Prolonged transmission time in autism. Psychiatry Res., 2: 157-166. 
78. Grilon, C., E. Courchesne and N. Akshoomoff, 1989. Brainstem and middle latency auditory evoked potentials in autism and developmental language disorder. J. Autism Dev. Disord., 19: 255-269.

79. Welsh, J.P., G. Yuen, D.G. Placantokanis, T.Q. Vu, F. Haiss, E. O'Hearn, M.E. Molliver and S.A. Aicher, 2002. Why do Purkinje cells die so easily after global brain ischemia? Aldolase C, EAAT4 and cerebellar contribution to posthypoxic myoclonus. Adv. Neutrol., 89: 331-359.

80. Fonnum, F. and E.A. Lock, 2000. Cerebellum as a target for toxic substances. Toxicol. Lett., 112-113: 9-16.

81. Cerrvos-Navarro, J.M. and N.H. Diemer, 1991. Selective vulnerability in brain hypoxia. Crit. Rev. Neurobiol., 6:149-182.

82. Courchesne, E., 1991. Neuroanatomic imaging in autism. Pediatrics, 87: 781-790.

83. Kemper, T.L. and M.L. Bauman, 1993. The contribution of neuropathologic studies to the understanding of autism. Neurol. Clin., 11: 175187.

84. Bailey, A., P. Luthert, A. Dean, B. Harding, I. Janota, M. Montgomery, M. Rutter and P.A. Lantos, 1998. A clinicopathological study of autism. Brain, 121: 889-905.

85. Townsend, J., E. Corchesne, J. Covington, M. Westerfield, N.S. Harris, P. Lyden, T.P. Lowry G.A. Press, 1999. Spatial attention deficits in patients with acquired developmental cerebellar abnormality. J. Neurosci., 19: 5632-5643.

86. Kern, J.K., 2003. Purkinje cell vulnerability and autism: possible etiological connection. Brain Dev., 25: 377-382.

87. Bauman, M.L. and T.I. Kemper, 2003. The neuropathology of the autism spectrum disorders: what have we learned? Norvatis Found. Symp., 251: 112-122.

88. Bauman, M.L. and T.L. Kemper, 2005. Neuroanatomic observations of the brain in autism a review and future directions. Int. J. Dev. Neurosci., 23: 183-187.

89. Hanakawa, T., I. Immish, K. Toma, M.A. Dimyan, P. Van Gelderen and M. Hallet, 2003. Functional properties of brain areas associated with motor execution and imagery. J. Neurophysiol., 89: 9891002.

90. Mari, M., U. Castiello, D. Marks, C. Maraffa and M. Prior, 2003. The reach-to-grasp movement in children with autism spectrum disorder. Philos. Trans. R. Soc. Lond. B. Biol. Sci., 358: 393-403.
91. Schmahmann, J.D., 1991. An emerging concept. The cerebellar contribution to higher function. Arch. Neurol., 48: 1178-1187.

92. Trevarthen, C., 2000. Autism as neurodevelopmental disorder affecting communication and learning in early childhood: prenatal origins, postnatal course and effective educational support. Prostaglandins Leukot. Essent. Fatty Acids, 6: 41-46.

93. Riva, D. and C. Giorgi, 2000. The cerebellum contributes to higher functions during development: evidence from a series of children surgically treated for posterior fossa tumors. Brain, 123: 1051-1061.

94. Pierce, K. and E. Courchesne, 2001. Evidence for a cerebellar role in reduced exploration and stereotyped behavior. Biol. Psych. 49: 655-664.

95. Buyske, S., T.A. Williams, A.E. Mars, E.S. Stenroos, S.X. Ming, R. Wang, M. Sreenath, M.F. Factura, C. Reddy, G.H. Lambert and W.G. Johnson, 2006. Analysis of case-parent trios at a locus with a deletion allele: association of GSTM1 with autism. BMC Genet., 7: 8.

96. Serajee F.J., R. Nabi, H. Zhong and M. Hug, 2004. Polymorphism in xenobiotic metabolism genes in autism. J. Child Neurol., 19: 43-47.

97. Moreira, P.I., S.L. Siedlak, G. Aliev, X. Zhu, A.D. Cash, M.A. Smith and G. Perry, 2005. Oxidative stress mechanisms and potential therapeutic in Alzheimer disease. J. Neural. Transm., 112: 921932.

98. Liochev, S.I. and I. Fridovich, 1999. Superoxide and iron; partners in crime. IUBMB Life, 48: 157161.

99. Good, P.F., P. Werner, A. Hsu, C.W. Olanov and D.P. Perl, 1996. Evidence of neuronal oxidative damage in Alzheimer's disease. Am. J. Pathol., 149: 21-28.

100.Nunomura, A., G. Perry, G. Aliev, K. Hirai, A. Takeda, E.K. Balraj, P.K. Jones, H. Ghanbari, T. Wataya, S. Shimohama, S. Chiba, C.S. Atwood, R.B. Petersen and M.A. Smith, 2001. Oxidative damage is the earliest event in Alzheimer disease. J. Neuropathol. Exp. Neurol., 60: 759-767.

101.Butterfield, D.A., T.T. Reed, M. Perluigi, C.D. Marco, R. Coccia, J.N. Keller, W.R. Markesbery and R. Sultana, 2007. Elevated levels of 3nitrotyrosine in brain from subjects with amnestic mild cognitive impairment; Implications for the role of nitration in the progression of Alzheimer's disease. Brain Res., 1148: 243-248.

102.Gillberg, I.C., C. Gillberg and S. Kopp, 1992. Hypothyroidism and autism spectrum disorders. J. Child. Psychol. Psychiatry, 33: 531-542. 